\title{
International Trade in Meat: The Tip of the Pork Chop
}

This paper provides an original account of global land, water, and nitrogen use in support of industrialized livestock production and trade, with emphasis on two of the fastest-growing sectors, pork and poultry. Our analysis focuses on trade in feed and animal products, using a new model that calculates the amount of "virtual" nitrogen, water, and land used in production but not embedded in the product. We show how key meatimporting countries, such as Japan, benefit from "virtual" trade in land, water, and nitrogen, and how key meatexporting countries, such as Brazil, provide these resources without accounting for their true environmental cost. Results show that Japan's pig and chicken meat imports embody the virtual equivalent of $50 \%$ of Japan's total arable land, and half of Japan's virtual nitrogen total is lost in the US. Trade links with China are responsible for $15 \%$ of the virtual nitrogen left behind in Brazil due to feed and meat exports, and $20 \%$ of Brazil's area is used to grow soybean exports. The complexity of trade in meat, feed, water, and nitrogen is illustrated by the dual roles of the US and The Netherlands as both importers and exporters of meat. Mitigation of environmental damage from industrialized livestock production and trade depends on a combination of direct-pricing strategies, regulatory approaches, and use of best management practices. Our analysis indicates that increased water- and nitrogen-use efficiency and land conservation resulting from these measures could significantly reduce resource costs.

\section{INTRODUCTION}

Livestock have long provided valuable food, fiber, fertilizer, fuel, traction, and transport to humans and have had significant impacts on the evolution of human societies (1). Traditionally, livestock have been an integral part of agricultural systems, distributed among many owners and raised close to their feed source. Increases in meat demand, cheap feed costs, improved transport, and changes in the technology and organization of animal production are now creating new patterns of both production and consumption $(2,3)$. In this paper, we show how livestock industrialization and trade are affecting the appropriation of resources and discharge of effluents in key meatproducing and meat-consuming nations.

At the beginning of the nineteenth century, annual global meat consumption was about $10 \times 10^{6} \mathrm{t}(\sim 10 \mathrm{~kg}$ per capita $)$, and most of the meat came from animals raised primarily in small-holder operations using local resources of land, water, and nutrients (4). By 1961 (the oldest global record) (5), global meat consumption had increased to about $73 \times 10^{6} \mathrm{t}(\sim 23 \mathrm{~kg}$ per capita) (6).

At the beginning of the twenty-first century, global meat production was $243 \times 10^{6} \mathrm{t}$ (Table 1), and per-capita supplies of meat had increased to $\sim 40 \mathrm{~kg} \mathrm{yr}^{-1}$ on average and to $\sim 80 \mathrm{~kg}$ $\mathrm{yr}^{-1}$ in developed countries. Half of the increase occurred over the last 25 y (5), a trend likely to continue given a projected doubling of meat demand in developing countries over the next three decades $(7,8)$. Trade has been growing even faster than production. Globally, the share of trade as a share of total meat consumption increased from $9.2 \%$ in $1979-1981$ to $12.8 \%$ in 1999-2001. A number of developing countries such as Mexico, Korea, Philippines, Malaysia, and the Near East countries are important net importers of livestock products, and they will likely be even more dependent on imports in future.

Expansion in the livestock sector is worrisome in light of the burden it places on natural resources globally. Livestock's use of land is perhaps the most obvious example. At the beginning of the twenty-first century, $7 \%$ of Earth's ice-free land was used to grow crops for direct human consumption, and $30 \%$ was used to grow feed and forage for animals (including arable land and pasture) (4). Given the traditional use of less-productive land for livestock grazing, this $4: 1$ ratio of land devoted to animal food relative to direct human food is not new. But the contemporary rapid industrialization of livestock production, coupled with the growing production of nonruminants (pigs and chickens) relative to ruminants (cattle, sheep and goats, which primarily graze), is increasing demand for arable land and the water and nutrients associated with its use.

Table 1 shows estimated meat production, feed use, and conversion rates of feed from different sources by ruminants and nonruminants (9). Pigs and chickens now account for $70 \%$ of total meat production (in carcass weight), where industrialized systems provide over half the pork and almost threequarters of poultry production. Industrialization has been associated with regional concentration and can be observed in most developed and developing countries alike (4); the trend toward both industrialization and regional concentration is particularly strong in countries with strong sector growth like China and Brazil.

Industrialized systems are based on diets containing large amounts of cereal grains and oil meals, in contrast to traditional systems, which use larger amounts of by-products and waste products, and, for ruminants, crop residues and forages. As the most industrialized systems, pork and poultry production now account for over $75 \%$ of cereal- and oilseed-based concentrate feeds while using small amounts of by-products and little or no crop residues or forages. Their influence on feed resources is therefore quite striking. Although ruminants consume $69 \%$ of animal feed overall, nonruminants consume $72 \%$ of all animal feed that is grown on arable land. Based on all feed consumed, ruminants convert this to meat much less efficiently than nonruminants, due to the lower quality of feed and other factors, but the majority of ruminant feed is forage from nonarable land and other materials humans cannot eat. Nonruminants, on the other hand, consume large amounts of feed grown on land that could grow food crops, bringing them into inevitable conflict with other potential uses for arable land. Thus, as industrial animal production continues to increase, competition between feed and food crop production for land and other resources will increase.

The growth in production of nonruminants relative to ruminants has been driven by declining real prices for feed grains and the higher relative feed-conversion efficiencies of 
Table 1. Global meat production and estimated feed use, 2002 (million tonnes).

\begin{tabular}{|c|c|c|c|c|c|}
\hline & \multicolumn{2}{|c|}{ Ruminants } & \multicolumn{3}{|c|}{ Nonruminants } \\
\hline & Beef & Sheep and goat & Pork & Poultry & Total \\
\hline Production (carcass weight) & 61 & 12 & 95 & 75 & 243 \\
\hline Production, industrialized & 4.1 & 0.1 & 52 & 54 & 110 \\
\hline \multicolumn{6}{|l|}{ Estimated concentrate feed inputs } \\
\hline Cereals & 87 & 7 & 221 & 121 & 436 \\
\hline Oilseed meals & 36 & 2 & 91 & 50 & 179 \\
\hline Roots and tubers & - & - & 85 & 14 & 99 \\
\hline Total & 123 & 9 & 397 & 185 & 714 \\
\hline \multirow{2}{*}{\multicolumn{6}{|c|}{ Estimated total feed inputs and conversion rates }} \\
\hline & \multicolumn{2}{|c|}{ Ruminants } & \multicolumn{3}{|c|}{ Nonruminants } \\
\hline Cereals & \multirow{2}{*}{\multicolumn{2}{|c|}{$\begin{array}{l}94 \\
38\end{array}$}} & \multirow{2}{*}{\multicolumn{3}{|c|}{342}} \\
\hline Oilseeds & & & & & \\
\hline Roots and tubers & \multicolumn{2}{|c|}{-} & \multicolumn{3}{|c|}{99} \\
\hline Forage (arable) & \multicolumn{2}{|c|}{90} & \multicolumn{3}{|c|}{ - } \\
\hline Total from arable land & \multicolumn{2}{|c|}{222} & \multicolumn{3}{|c|}{582} \\
\hline By-products & \multicolumn{2}{|c|}{$\begin{array}{r}75 \\
350\end{array}$} & \multicolumn{3}{|c|}{75} \\
\hline Crop residues & \multirow{2}{*}{\multicolumn{2}{|c|}{$\begin{array}{l}350 \\
813\end{array}$}} & \multirow{2}{*}{\multicolumn{3}{|c|}{ - }} \\
\hline Forage (nonarable) & & & & - & \\
\hline Total & \multicolumn{2}{|c|}{1460} & \multicolumn{3}{|c|}{657} \\
\hline \multicolumn{6}{|l|}{ Conversion rate } \\
\hline Total feed to meat & \multicolumn{2}{|r|}{0.05} & \multicolumn{3}{|c|}{0.26} \\
\hline Feeds from arable land to meat & \multicolumn{2}{|r|}{0.33} & \multicolumn{3}{|c|}{0.29} \\
\hline
\end{tabular}

nonruminants. If grains become much more expensive, the economic advantage of nonruminants may decrease. However, the amounts of grazing land, crop residues, and by-products potentially available are not sufficient to permit a large increase in ruminant production, especially given the recent biofuel expansion. Thus, projected increases in demand for meat will likely be met primarily by nonruminants.

\section{THE IMPORTANCE OF TRADE}

This increased reliance on concentrate feeds in animal production, coupled with growing trade liberalization and improved transportation infrastructure and technology, has resulted in a concomitant rise in feed trade as increasingly mobile producers purchase feed on a least-cost basis from international markets. Trade in maize and soy, two primary feed crops, has grown at $2.8 \%$ and $7.0 \%$ annually over the past decade; these rates are higher than anything seen over the preceding two decades (5).

Trade in meat and meat-products, while only one-tenth the volume of feed trade, is also growing very rapidly, particularly for nonruminants. Over the past decade, world trade in pig meat and chicken meat has grown at annual rates of 5.6\% and $6.8 \%$, respectively (5), which is roughly equal to a doubling in trade volume every $10-12 \mathrm{y}$. Trade as a percentage of total production is also growing rapidly for pork and poultry, having doubled over the past two decades to roughly $10 \%$ for both sectors (5). Meat trade expansion will likely continue until at least 2050 (4).

While an increase in meat consumption and trade generally indicates favorable income growth and more abundant highquality protein, such growth is changing the relationship between meat production and the environment in often unappreciated ways. Rapid growth in trade of both feed and meat has severed the traditional links between livestock and the local resource base. For instance, nutrient output from intensive animal production often exceeds the absorptive capacity of the surrounding area, and increasing transport costs and distances mean that these nutrients are often not returned to the land in a productive manner. At the same time, increasing production of concentrate feeds takes its own environmental toll through the use and loss of fertilizer and pesticides, use of scarce water resources, or conversion of ecologically valuable land (16).
To the importer of the finished meat product, these myriad environmental effects are obscured by a production and trade system that both undervalues various environmental inputs and understates the potential environmental harm inherent in the production process. These effects can be significant. One study estimates that these external costs of US agricultural production (e.g., the cost of damages to people and ecosystems, government control, and clean-up processes not borne by producers or consumers) total between USD 9.4 and 20.6 billion per year (17). As trade separates meat consumers and the negative environmental impacts of meat production, meat importers are neither made to feel nor pay for the impacts of their consumption decisions - an arrangement that can lead to overuse and misallocation of environmental resources. Quantifying the real but hidden link between consumption and production is a policy-relevant issue that has been studied for other natural resource-intensive goods. For example, Chapagain et al. (18) showed that the economic and environmental externalities of water use are generally not included in the price paid by foreign consumers. In addition, cotton consumers in the EU25 countries are calculated to be indirectly responsible for about $20 \%$ of the desiccation of the Aral Sea (18). Analytically relinking consumption and the various stages of production is a first step in addressing these problems of trade-related resource use (3).

\section{QUANTIFYING THE IMPACT OF TRADE ON RESOURCE USE}

To calculate and make spatially explicit this resource use and transfer among countries, we developed the MEAT model (19). The model is a partial equilibrium model that estimates the land, water, and nitrogen inputs to feed and meat production using country-specific data such as yield, water-use efficiencies, and nitrogen-use efficiencies. Extensive data needs were met from a variety of sources, including publicly available agricultural and trade data and novel survey work. A full explanation of the model can be found in Burke et al. (19). The model tracks resource use at three different stages in the production process: feed production, live-animal production, and meat processing. Given the complex landscape of global production and trade, we limit our analysis to four representative case-study countries and their trading partners: Japan, one of the world's largest feed and meat importers; Brazil, one of the world's largest feed and meat 
Figure 1. Losses and flows of nitrogen associated with import (entering the "country-box" at the top), export (leaving the "countrybox" at the bottom) of chicken meat, pig meat, and related feed. The boxes within the country-box represent both domestic production and the embedded $\mathrm{N}$ that comes in through imports-as such, they represent the total amount of $\mathrm{N}$ involved in different stages of animal production; green $=$ feed, red $=$ live animal, blue $=$ processing. Black arrows represent embedded $N$ in both domestically consumed and traded product. Gray, curved arrows represent virtual nitrogen. Values are annual totals in thousand metric tons, averaged over the years 2000-2002.
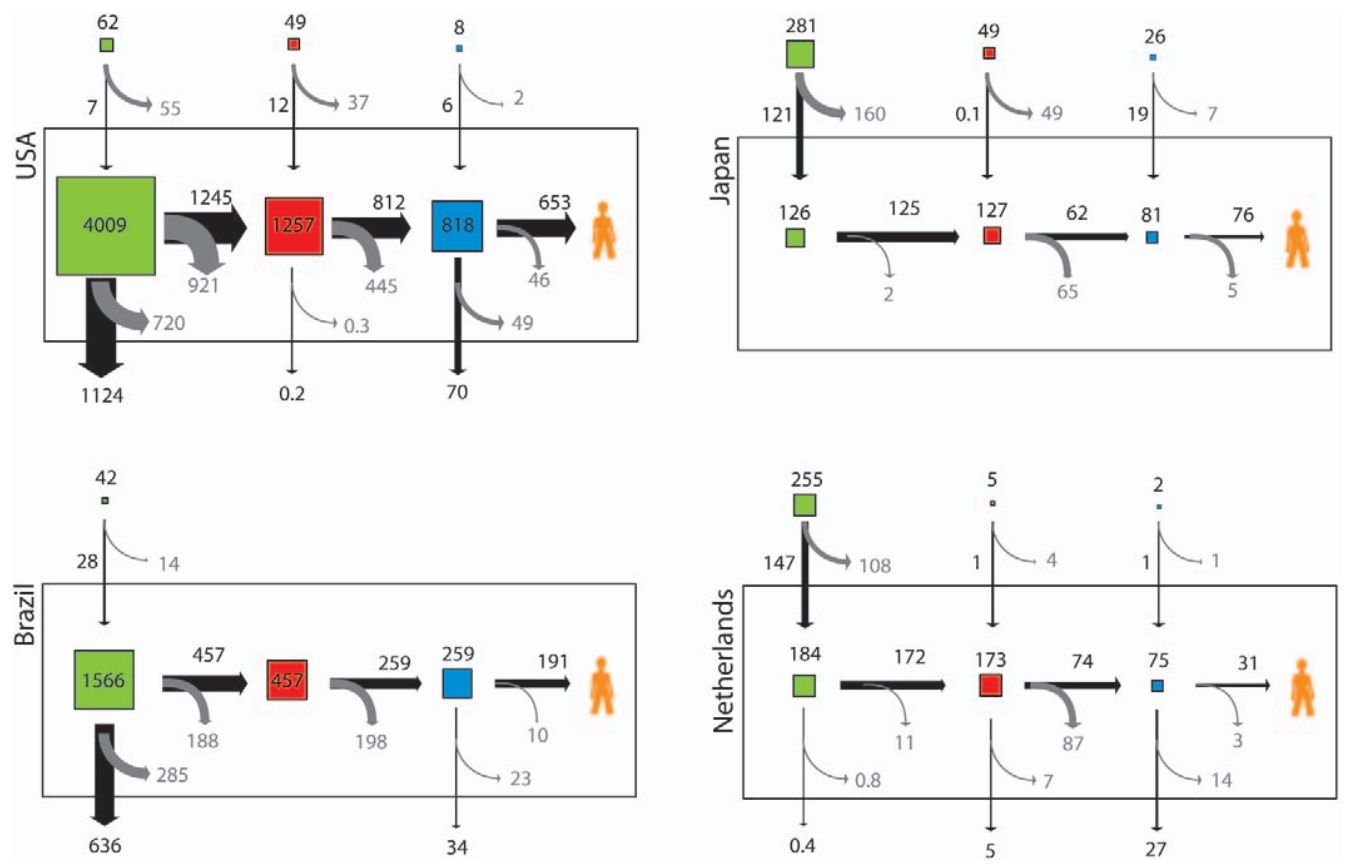

exporters; and the Netherlands and the US, which dominate on both the import and export side (5). The model analyzes the production and trade of pigs and chickens. While there are of course other important forms of protein production (dairy, eggs, beef, etc.), the high rate of industrialization and explosive global growth in trade and production of nonruminants make them particularly good examples of the evolving effects of livestock production on global environmental resources.

We focus on the land, water, and nitrogen use associated with trade and production. Water and land are critical limiting resources globally, and nitrogen is a key agricultural input, but it is also a potential environmental contaminant (20). The model calculates both the "virtual" and "embedded" resources involved in production, where "virtual" are those resources that are used in production but are not physically contained in the final product and "embedded" are the resources contained in the shipped product. These calculations allow us to trace in detail the use and flow of resources throughout the trading system. The model results demonstrate the effect of growth in industrialization and trade on the global distribution of livestock resource use and provide a necessary first step in relinking the consumption of industrialized meat products with environmental-resource consequences in other countries. A few recent studies have established linkages between production and consumption of goods and services in relation to water resources (21-24). However, there is hardly any literature available showing such linkages in the case of nitrogen or land. While the MEAT model does not explicitly estimate costs on either the input or output side, it provides the physical basis for a broader economic analysis of meat-related resource use.

\section{Nitrogen}

Many aspects of nitrogen (N) use and loss in agriculture, and the resulting human and environmental impacts, are well understood (e.g., 25-27). Attention to the role of international trade in $\mathrm{N}$-intensive agricultural goods, as both a physical transport mechanism of $\mathrm{N}$ and a driver of local $\mathrm{N}$ cycling, has been nascent, with attention focusing more on the former than the latter (e.g., 28). Here, we use the MEAT model to analyze the effect of international trade in meat products on $\mathrm{N}$ cycling within and between countries (19). Quantification of such linkages is crucial to understanding biogeochemical flows (e.g., nitrogen flows through and between environmental reservoirs) in a globalized world, particularly as the traditional on-farm links between animals, fertilizer, and crop production are broken (3). Furthermore, all the social and environmental costs of $\mathrm{N}$ loss from agricultural systems $(25,29)$ are rarely included in the price of the consumed products, suggesting that a meatimporting nation benefits from meat consumption without facing the costs of $\mathrm{N}$ loss within its own borders.

The consumption of imported meat entails the capture, use, and loss of nitrogen in farming systems around the world. Globally, nitrogen fertilizers applied to feed crops represent roughly $40 \%$ of the manufactured total, causing an emission of some $40 \mathrm{Tg} \mathrm{CO}_{2}$ (4), and much of the $\mathrm{N}$ not taken up by the crop is lost to the surrounding water and atmosphere. When feed crops are then fed to pigs and chickens in industrial production systems, concentrated quantities of $\mathrm{N}$ are lost from this stage in production due to excretion of feces and urine. Finally, relatively small amounts of $\mathrm{N}$ are lost during the meatprocessing stage, as parts of the animal carcass are discarded.

Figure 1 shows the virtual $(\mathrm{Nv})$ and embedded $(\mathrm{Ne})$ nitrogen associated with trade and production of pig meat and chicken meat in the four case-study countries. Our results raise four interesting points. First, feed production (green squares) swamps meat production (red + blue squares) in terms of both $\mathrm{Nv}$ and Ne, constituting roughly $70 \%$ of the totals of each. This result is important for policy, since it is typically more difficult to regulate non-point-source $\mathrm{N}$ pollution from field crops than it is to regulate point-source pollution from animal production.

Second, for all our case-study countries, the $\mathrm{N}$ value associated with trade is significant relative to that associated with domestic consumption. In Japan, for instance, roughly 220000 metric tons of $\mathrm{N}$ are left behind in other countries due to Japanese meat consumption, dwarfing the roughly 70000 metric tons that are released to Japan's environment due to domestic production. At the other extreme, in Brazil and the US, the amount of feed produced internally is large, and it is about equally split between domestic and foreign animal meat production. In other words, the environments of Brazil and the US are receiving large amounts of $\mathrm{N}$ to support animal production in other countries. Even in the Netherlands, a country for which domestic $\mathrm{N}$ loading has been a troubling and well-publicized issue, the amount of $\mathrm{Nv}$ left behind in other countries as a result of Dutch pork and poultry meat imports (largely in the form of feed) is roughly equal to that associated with total production within the country. Similarly, over $40 \%$ of 


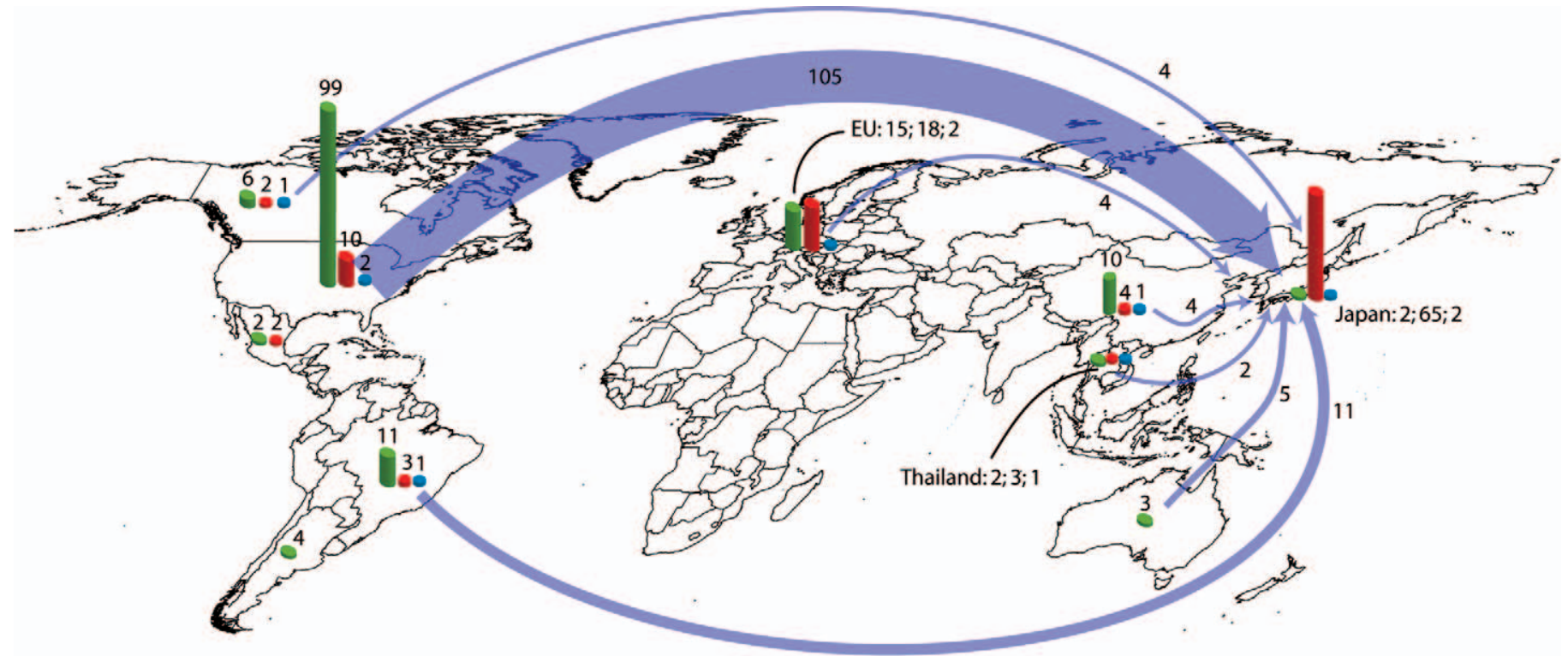

Figure 2. Nitrogen associated with the production of pigs and chickens consumed in Japan. Bars refer to $\mathrm{N}$ left behind in the producing country during different stages of production; green = feed; red = live-animal production; blue = meat processing. Arrows represent transfer of total $\mathrm{N}$ embedded in shipped product. Data are annual values in thousands of metric tons, averaged over the years $2000-2002$.

the $\mathrm{N}$ lost to the Brazilian environment is due to meat consumption in other countries.

Third, Ne totals are generally larger than Nv totals for the studied countries. For feed, this is largely due to the importance of legumes (particularly soy) in the diets of industrialized pigs and chickens, and the large amount of $\mathrm{N}$ shipped therein. But while trade in $\mathrm{Ne}$ could be problematic in the context of a country exporting its soil fertility (28), we contend that the Nv totals are arguably more important. From the importing country's perspective, $\mathrm{Ne}$ in meat typically enters the environment in the form of human waste after the meat is consumed; such waste is usually much better regulated and contained than the $\mathrm{N}$ lost from fields and animal-feeding operations.

Finally, the model illuminates the country-level determinants of meat-related resource use. For instance, of the 400000 metric tons of $\mathrm{Nv}$ left behind in Brazil due to feed and meat exports, 65000 metric tons result from trade links to China. Figure 2 visually demonstrates these linkages for Japan. It shows the flow of the Ne in pigs and poultry that is shipped to Japan, and the associated amount of $\mathrm{Nv}$ that is left behind in the producing countries due to feed production and live-animal production and processing. The figure suggests two things. First, much more $\mathrm{N}$ is lost in other countries as a result of Japanese pig and chicken consumption than is lost in Japan-about one-and-ahalf times as much. This result reflects Japan's role as a large importer of these products. In addition, Figure 2 and the trade data underlying it allow a comparison of the Ne shipped in the product and $\mathrm{Nv}$ left behind during production of the product.

For Japan, the Ne that arrives in the shipped product is $\sim 64 \%$ of the 220000 tons of total virtual nitrogen left behind in other countries. Japanese consumers thus enjoy the benefit of meat-eating without having to suffer the environmental cost of losing 220000 tons of $\mathrm{N}$ to local ground and surface water and to the local atmosphere. When tracing Japan's feed and meat imports, more virtual $\mathrm{N}$ is left behind in the US than any other country. Our calculations show that about 110000 tons of $\mathrm{N}$ are lost each year to the environment in the US due to meat consumption in Japan, adding to already high $\mathrm{N}$ loads in some feed- and meat-producing areas in the US. Such an analysis is useful because it relinks consumption and productionanalytically if not physically - and therefore provides a more spatially precise and quantitatively accurate resource-use story.

\section{Water}

In an increasingly water-scarce world, different uses for freshwater are necessarily in competition. Agriculture dominates global water use, dwarfing the next highest use, domestic water supply, by a factor of three (30). This fact reflects not only agriculture's water dependence but also the relatively low cost of water that farmers pay relative to urban users, and the consequent inefficient use (31-34). If the price of water signaled its true scarcity, water-use efficiencies would likely improve, a significant amount would be redirected to other uses, and water-intensive goods would become more costly. Water's underpricing implies that nations, by exporting feed or meat (both water-intensive goods), have little incentive to use the resource efficiently and thus could diminish or deplete a crucial resource without receiving proper compensation (35).

During the era when meat was predominantly raised by traditional, nonintensive means, meat production did not compete with other activities for water inputs. By contrast, current industrialized livestock production, primarily through its dependence on crop-based feed, requires immense amounts of water and directly competes with other end users. As with nitrogen, the MEAT model quantifies the water used for industrialized meat production for all three phases of production, and it tracks the origin, transport, and destination of the water for each case study. For animal production and processing, we simply estimated the total water used. For feed production, however, we calculated only the irrigation water required to grow the feed crops, disregarding rainwater. We focus on irrigation water because it is typically dramatically underpriced and has obvious alternative uses.

For all three phases, but especially for feed production, our "total virtual" numbers should be interpreted with care. Most of the water withdrawn to grow a crop is either evapotranspired (becoming a potential contributor to downwind precipitation), or it percolates beyond the reach of roots and enters groundwater or nearby streams (becoming available for potential uses downstream). Similarly, water used in animal production and processing does not all get used by the animal or processing plant. Nonetheless, all three phases could pollute the water, rendering it useless unless it undergoes costly treatment. At the global scale, determining reuse coefficients and coupling quantity and quality become intractable. Our 
Figure 3. Losses and flows of water associated with import, export, and domestic production of chicken meat, pig meat, and related feed. Boxes, arrows, and colors are as in Figure 1, with values in millions of cubic meters.
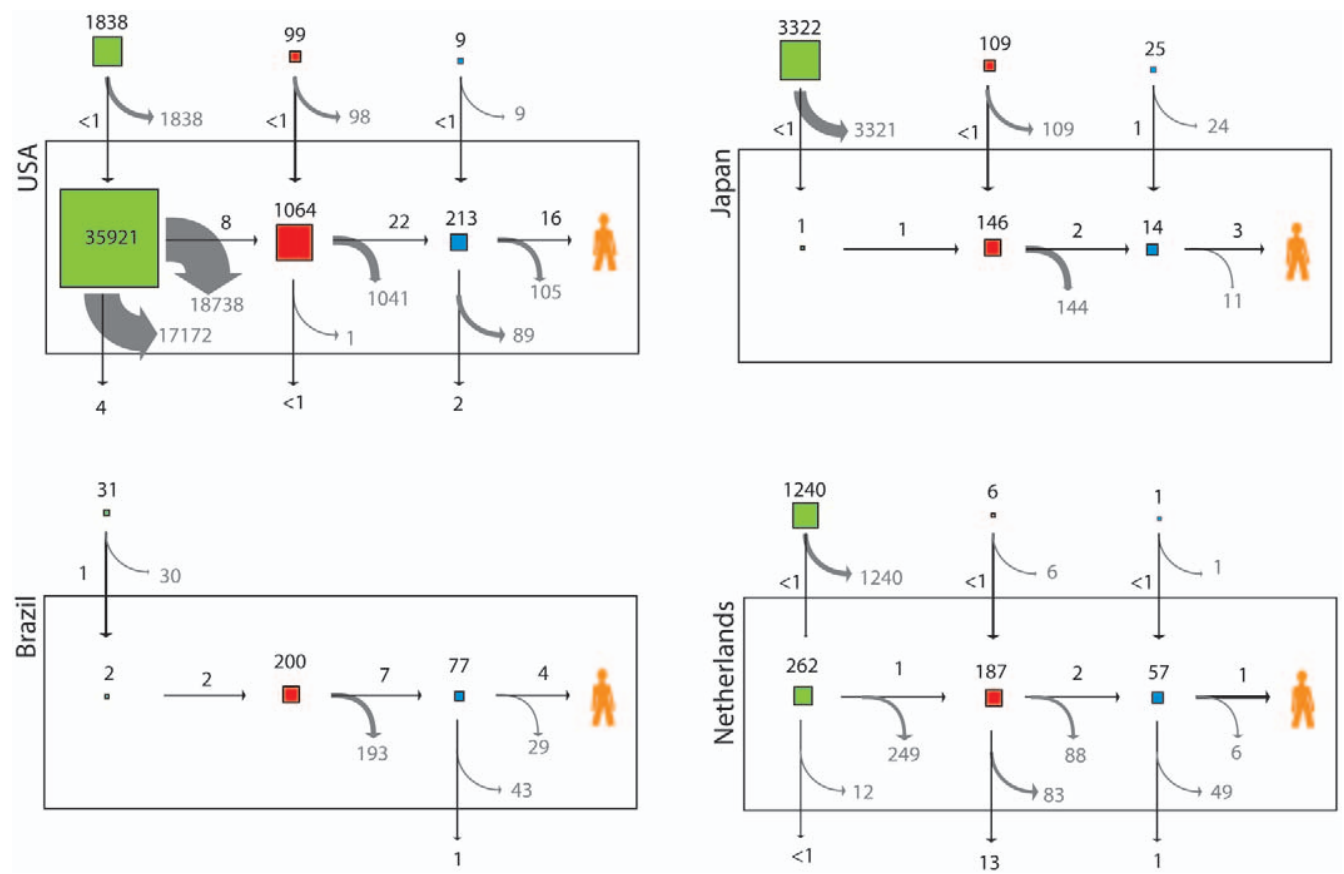

model therefore highlights the spatial distribution of water use in meat production without regard to reuse or pollution.

Figure 3 shows the virtual (Wv) and embedded water (We) associated with trade and production of pork and poultry in the four case-study countries. Perhaps not surprisingly, water use in the service of livestock production is overwhelmingly concentrated in the feed-production stage (green boxes).

The US is particularly dominant in this respect, and the large Wv totals reflect its relatively high reliance on irrigated water for feed production. We calculate that total irrigated water used for production of feed and meat for export in the US is $20 \mathrm{~km}^{3}$, or roughly $5 \%$ of total US water withdrawals annually (30). While this might seem small at the national level, the local effects of water overuse can be significant. Corn, the US's largest animalfeed export, is a good example. Roughly $15 \%$ of the area under corn production in the US is irrigated (36). Our calculations show that annual US corn production requires $6.9 \mathrm{~km}^{3}$ of irrigation water, almost $20 \%$ of which is used to grow exported corn. Most irrigated corn-growing areas (Nebraska, Kansas, eastern Colorado, the panhandle of Oklahoma, and northern Texas) draw their irrigation water from the Ogallala aquifer, which is the largest underground water resource in the US, and its groundwater levels have declined an average $3.8 \mathrm{~m}$ due to primarily agricultural withdrawals (37). The Ogallala provides over 2 million people with drinking water, and as its overdraft worsens and competing uses intensify, conflicts over use will continue to escalate. Through its corn exports, the US is rapidly depleting a scarce environmental resource and exacerbating water conflicts, while not being fully compensated for its loss.

Figure 3 also demonstrates that unlike nitrogen, shipments of meat and feed contain little of the water that was used to produce them. Nevertheless, by importing feed or meat, a country is essentially importing water, in the sense of having to use less of its own water to support a given level of meat consumption. In population-dense Japan, the $3.5 \mathrm{~km}^{3}$ of $\mathrm{Wv}$ associated with Japanese imports of feed and meat represents roughly $5 \%$ of its total water use, suggesting that the country is able to virtually import a nontrivial amount of water through its consumption of feed and meat produced abroad.

\section{Land}

As Table 1 suggests, the trend toward industrialized nonruminant meat production affects the character of land use by increasing the demand for feed from arable land. Both the industrialization of a portion of ruminant production through the development of feedlots and the rapid growth in the concentrate-consuming pig and poultry sectors contribute to this, although the latter has a much greater effect. While the need for grazing land is not decreasing, the number of ruminant animals globally continues to increase at a much slower rate than that of nonruminants. And while grazing is itself not without problems (e.g., 38), the use of arable land arguably has greater costs to both society and the environment, including the suite of environmental impacts associated with intensive crop production such as pesticide and fertilizer use and loss (16), fullscale land conversion in some areas, and large opportunity cost with respect to other human and environmental uses (food or fuel production for humans, animal habitat, etc.). As with water and nitrogen, many of these negative effects on land resources are not included in the final price of the sold product (39).

Model calculations show that land use associated with industrialized pig and chicken production is substantial, and the international trading system allows meat and feed importers to escape what would otherwise be binding land constraints. For instance, we calculate that consumption of pig meat and chicken meat in Japan entails the use of roughly $2.2 \times 10^{6}$ ha of land in other countries for feed production (Table 2), which is equal to $50 \%$ of the total arable land in Japan.

The model also highlights the determinants of land use and land conversion in a given area. For instance, the rapid expansion of soy production in Brazil has been decried for its devastating effects on Brazilian savannah and rainforest ecosystems (e.g., 40, 41), and this expansion has been linked to growth in global meat production (42). We calculate that

Table 2. Land use associated with import, export, and production for domestic consumption of pig meat, chicken meat, and related feed. We assume that animal production and processing are landless. Data are in thousands of hectares.

\begin{tabular}{lccr} 
& Import & $\begin{array}{c}\text { Domestic } \\
\text { consumption }\end{array}$ & Export \\
\hline US & 1041 & 8469 & 9013 \\
Brazil & 380 & 5073 & 5611 \\
Japan & 2168 & 25 & 0 \\
Netherlands & 1215 & 44 & 64 \\
\hline
\end{tabular}


roughly $11 \times 10^{6}$ ha in Brazil go to feed industrialized pigs and chickens, with a little over half of this acreage devoted to production for export. Most of Brazil's land used to grow soy exports is associated with pig and chicken production in Europe, although, in the past half-decade, China has emerged as a huge importer of Brazilian soy. Our results show that China is responsible for about $20 \%$ of the roughly $4 \times 10^{6}$ ha of soy exported from Brazil as pig and chicken feed.

\section{TRADE, RESOURCE COSTS, AND MITIGATION}

Increased industrialization of meat production and growing international trade in meat and feed substantially alter the magnitude and pattern of global resource use. Much of this meat-related growth in trade would occur even if there were no price distortions or if the costs of the environmental effects (socalled externalities) were borne by those who created them. Differences in country resource endowments, such as land and water, help dictate the location of production, and the trade flows that we have documented reflect, in part, the positive welfare gains from such trade. The major policy concern in this paper, however, is rather different. When negative externalities and price distortions in both input and output markets are not properly accounted for, as is surely the case for the three resources discussed here, public welfare and environmental services can be diminished in significant ways. Our policy perspective, therefore, is not antitrade, but rather asks what can be done to reduce environmental costs by linking those costs to the relevant producers and consumers. As a sensitivity analysis of our model demonstrates, successful reduction of these damages must rely on regulatory approaches, improvements in best practices, and pricing strategies that reflect the social costs of production.

Improvements in environmental outcomes with respect to nitrogen and meat production hinge on the nature of nitrogen loss. Our case studies suggest that dispersed (or "non-pointsource") nitrogen losses from feed production are more than twice the total point-source losses from pig and chicken feeding operations. Past policy measures, however, have proven much more successful at dealing with the latter than the former, particularly in the US context. Regulations surrounding manure storage and disposal, and novel strategies such as the former system of tradable manure quotas in the Netherlands (43) have had some success in reducing point-source $\mathrm{N}$ runoff from feeding operations in many areas. In Denmark, substantial reductions in nitrogen surplus have been achieved by tying livestock densities to availability of surrounding land for waste application. However, the costs of these programs can be prohibitive to producers and must be designed carefully. Further improvements in animal feed-conversion efficiencies (FCR, kg feed per $\mathrm{kg}$ meat), either through precise feed formulation or advances in breeding, would also result in a substantial decrease in $\mathrm{N}$ losses in both feeding operations and feed production; model calculations suggest that a $10 \%$ global increase in FCR for pigs and chickens reduces total $\mathrm{N}$ losses associated with pig and chicken production by roughly the same amount. The availability of new feed sources, for example, single-cell protein produced as a by-product of ethanol fermentation from corn, which has recently come into use as a livestock feed, could change $\mathrm{N}$ flows appreciably. The ability of livestock to convert materials that humans cannot digest or choose not to eat into desired human food offers a means of utilization of this and other nontraditional feed sources as they may become available, potentially sparing cropland and associated resources used for feed production.

On-farm management decisions during feed production could also have large effects on the total $\mathrm{N}$ losses related to meat production. We calculate that an improvement in crop nitrogen-use efficiency (NUE, defined as the amount of farmerapplied $\mathrm{N}$ removed in aboveground biomass) from a global average of $30 \%$ to $40 \%$ would reduce the total amount of $\mathrm{N}$ loss in feed-producing countries by $10-12 \%$. Growing feed crops with excess nitrogen application in rainy seasons or with excess irrigation reduces NUE. Considerable increases in efficiency can be achieved with some combination of changes in input prices (such as a nitrogen tax), regulations surrounding fertilizer application rates or absorptive buffer areas adjacent to sensitive riparian areas, or (perhaps most promisingly) better temporal and spatial information regarding $\mathrm{N}$ requirements at the field level. Such information has been shown in some cases to improve NUE by $20 \%$ or greater in intensively irrigated systems (e.g., 44), and such an approach is particularly appealing given the political obstacles to adopting pollution taxes.

Environmental issues surrounding water use associated with meat production relate both to water's scarcity and its overuse as an input. Severe underpricing of irrigation water, especially of surface flows used in feed production, exacerbates the overuse of water. Unfortunately, recent advances in the theory of water pricing have not been matched by an improved ability to overcome institutional constraints to the adoption of more "rational" water policies. Moreover, current rates of water use by the sector, particularly groundwater extraction rates in many major feed-producing areas, are often unsustainable (45).

Our model results suggest that a $10 \%$ improvement in irrigation efficiency would reduce total water use by the industrialized pig and chicken sectors by roughly the same amount. Based on estimates of farmer response to changing water prices (46), prices for irrigation water in developed countries would need to rise roughly $50-120 \%$ from current levels for total irrigated water use to fall $10 \%$ - a reasonable price increase, perhaps, given the frequently observed factor of ten (or greater) difference between municipal and agricultural prices for water (e.g., 45). The viability of new pricing schemes for water will depend heavily on whether irrigation water is sourced from groundwater or surface water, and whether the water provision is public or private. Groundwater, which is privately pumped to supply much of the irrigated water in major US feed-producing areas (36), is in theory more easily metered and is subject to rising pumping costs as aquifers shrink and energy becomes more expensive. Surface-water pricing is not subject to the same economic logic. In the absence of changed institutional arrangements, farmers receive minimal economic signals for altering irrigation practices.

As with water and nitrogen, land-use decisions around the world are typically made irrespective of the land's ecosystem services or true social value because these services are rarely marketable, priced, or enjoyed by the landowner. In "mature" agricultural systems, such as the US and Europe, opportunities for agricultural land expansion are low, and rising global feed demand may result in substitutions among crops rather than an expansion in total cropped area. Even in the US, however, some movement of feed production into areas with conservation value is possible, especially if maize and other feeds are increasingly devoted to biofuel production. In other systems, such as soy production in Brazil, growing feed demand now contributes to cropland expansion into natural ecosystems (e.g., 47, 48) at a potentially large cost to biodiversity and the global climate.

While "getting prices right" with respect to land, either through land taxes or payments for environmental services, appears in some instances to be a feasible option for reducing deforestation rates (e.g., 49), the remote nature of many expansion hotspots, such as those in Brazil, does not easily lend itself to regulatory or pricing approaches. Our model results suggest that this primary expansion is most sensitive to changes in soy yield and to the quantity of demand for meat and feed from abroad. For a given level of feed output, a $10 \%$ 
increase in soy yield would decrease land requirements by an equal amount. (This is not to suggest that increasing yields will take currently farmed land out of production, but simply that increasing yields could help retard future growth in area planted.) All other things being equal, a $10 \%$ reduction in export of Brazilian soybeans going to feed pigs and chickens abroad (which could come from a reduction in total demand for meat abroad, or an improvement in feed-conversion efficiencies) would reduce the total amount of pig- and chicken-devoted crop acreage in Brazil by $7 \%$. Perhaps more promising are "downstream" approaches to improving best practices with respect to land conversion, such as the recent decision by a large soy producers' association in Brazil not to buy products from recently deforested areas, following pressure from environmental and consumer groups.

In addition to policies regulating industrialized meatproduction systems, broader trade and commodity policies also affect environmental outcomes, sometimes reinforcing and sometimes offsetting direct policies implemented to protect natural resources or control pollution. Excessive use of water and nitrogen in these industrialized systems results from underpriced inputs as well as from crop prices distorted by more general policy incentives in agriculture. This point is clear in the case of Japan. Removal of price-distorting commodity protection polices for feed and meat would result in lower prices and larger Japanese imports of these items (50), since high domestic prices are one reason that Japan's per capita consumption of pork is only $62 \%$ of that in the US (5). Therefore, liberalization of Japanese markets, other things being equal, would add to the pressure on environmental resources abroad by leading to a rise in Japanese imports of agricultural commodities. Careful scenario analysis in a general equilibrium framework could be useful in sorting out the distribution of environmental impacts arising from such a policy shift, drawing on the policy's effects on input and output prices, production, and trade.

Observed meat trade, then, is just the tip of the pork chop, obscuring a global cascade of effects on nitrogen, water, and land resources. At the turn of the twenty-first century, $72 \%$ of poultry and $55 \%$ of pigs were raised in global industrialized animal-production systems sustained by feed from other regions and often consumed far from the point of production. This increased industrialization of meat production and growing international trade in meat and feed substantially alter the magnitude and pattern of global resource use and result in rising pressure on environmental resources in producing regions to sustain feed and meat use in consuming regions.

Our analysis identifies the uses of nitrogen, water, and land that sustain the growing demand for meat production and trade and suggests links and possible control points that could optimize the production of meat while minimizing the environmental consequences. As noted previously, careful general equilibrium modeling of livestock trade that includes additional resource costs could be a useful next step in identifying policies to reduce livestock's impact on the environment. Until consumers see meat prices that reflect full resource costs, resources will continue to be stressed by the growing industrial livestock sector.

\section{References and Notes}

1. Diamond, J. 1997. Guns, Germs and Steel. W. W. Norton \& Company, New York, 480 pp. 2. Delgado, C., Rosegrant, M., Steinfeld, H., Ehui, C. and Courbois, C. 1999. Livestock to 2020: The Next Food Revolution. Food, Agriculture and the Environment Discussion Paper No. 28. International Food Policy Research Institute, Washington, DC, 72 pp. 3. Naylor, R., Steinfeld, H., Falcon, W., Galloway, J., Smil, V., Bradford, E., Alder, J. and Mooney, H. 2005. Losing the links between livestock and land. Science 310, 1621-1622. Mooney, H. 2005. Losing the links between livestock and land. Science 310, 1621-1622.
Steinfeld, H., Gerber, P., Wassenaar, T., Castel, V., Rosales, M. and de Haan, C. 2006. Livestock's Long Shadow: Environmental Issues and Options. Food and Agriculture Livestock's Long Shadow: Environm

Food and Agriculture Organization (FAO). 2006. FAO statistical databases. (http:/ faostat.fao.org/default.aspx)
. Essemyr, M. 1983. Food Consumption and Standards of Living. Uppsala Papers in Economic History, Research Report No. 2. Uppsala University, Uppsala, Sweden, 23 pp. Food and Agriculture Organization (FAO). 2005. Livestock Policy Brief 02. FAO, Rome, 8 pp. (http://www.fao.org/AG/AGAINFO/resources/documents/pol-briefs/02 EN/AGA02_EN_08.pdf)

8. Food and Agriculture Organization (FAO). 2006. World Agriculture: Towards 2030 2050 Interim Report. Global Perspective Studies Unit, FAO, Rome, 71 pp. (http://www. fao.org/es/ESD/AT2050web.pdf)

9. The estimates are derived from data from references 5 and $10-13$ and calculations by the authors. The total amount of feed for ruminants was calculated as 1460 million metric tons $(73 / 0.05$, where the 0.05 average value was based on estimates ranging from 0.01 to $0.08 ; 12,14$ ); the amount from nonarable land (for which there appear to be no published estimates) was obtained by subtracting the estimate of feed from arable land from this total. Amounts of by-products and crop residues were based on estimated global amounts available (15) and assumptions about the proportions fed to different species.

0. Hendy, C.R.C., Kleih, U., Grashaw, R. and Phillips, M. 1995. Interaction between Livestock Production Systems and the Environment: Concentrate Feed Demand. FAO Consultancy Report for Livestock and the Environment Study (see 9), Greenwich, $141 \mathrm{pp}$.

11. de Haan, C., Steinfeld, H. and Blackburn, H.W. 1997. Livestock Environment Interactions: Finding a Balance. Report of a Study Coordinated by FAO, USAID and World Bank. $115 \mathrm{pp}$

12. Council for Agricultural Science and Technology (CAST). 1999. Animal Agriculture and Global Food Supply. Report No. 135. Council for Agricultural Science and Technology, Ames, Iowa, $92 \mathrm{pp}$

13. Steinfeld, H., Wassenaar, T. and Jutzi, S. 2006. Livestock production systems in developing countries - status, drivers, trends. OIE Sci. Tech. Rev. 25, 505-516.

14. Smil, V. 2000. Feeding the World: A Challenge for the Twenty-First Century. The MIT Press, Cambridge, MA, 360 pp.

15. Fadel, J.G. 1999. Quantitative analysis of selected plant by-product feedstuffs, a global perspective. Anim. Feed Sci. Tech. 79, 255-268.

16. Tilman, D., Cassman, K.G., Matson, P.A., Naylor, R. and Polasky, S. 2002 Agricultural sustainability and intensive production practices. Nature 418, 671-677.

17. Tegtmeier, E. and Duffy, M. 2004. External costs of agricultural production in the United States. Int. J. Agric. Sustain. 2, (1), 1-20.

18. Chapagain, A.K. 2006. Globalisation of Water: Opportunities and Threats of Virtual Water Trade. A.A. Balkema Publishers, Leiden, The Netherlands, $162 \mathrm{pp}$.

19. Burke, M., Oleson, K., McCullough, E. and Gaskell, J. 2006. Modeling the externalities of meat production and trade. CESP Working Paper. Center for Environmental Science and Policy, Stanford, CA, $40 \mathrm{pp}$.

20. We acknowledge that phosphorus and other nutrients as well as energy needs are also important and suggest that any future analysis building on our model include them.

21. Chapagain, A.K., Hoekstra, A.Y. and Savenije, H.H.G. 2006. Water saving through international trade of agricultural products. Hydrol. Earth Sys. Sci. 10, 455-468.

22. Chapagain, A.K. and Hoekstra, A.Y. 2004. Water footprints of nations. In: Value of Water Research Report Series No. 16. UNESCO-IHE,16. Delft, The Netherlands, 76 pp. 3. Hoekstra, A.Y. and Hung, P.Q. 2005. Globalisation of water resources: international virtual water flows in relation to crop trade. Global Environ. Chang. 15, 45-56.

24. Chapagain, A.K., Hoekstra, A.Y., Savenije, H.H.G. and Gautam, R. 2006. The wate footprint of cotton consumption: an assessment of the impact of worldwide consumption of cotton products on the water resources in the cotton producing countries. Ecol. Econ. 60, 186-203.

25. Smil, V. 1999. Nitrogen in crop production: an account of global flows. Global Biogeochem. Cy. 13, 647-662.

26. Cassman, K.G., Dobermann, A. and Walters, D.T. 2002. Agroecosystems, nitrogen-use efficiency, and nitrogen management. Ambio 31, 132-140.

27. Galloway, J.N Aber, J.D., Erisman, J.W Seitzinger, S.P., Howarth, R.W Cowling, E.B. and Cosby, B.J. 2003. The nitrogen cascade. Bioscience 53, 341-356.

28. Grote, U., Craswell, E. and Vlek, P. 2005. Nutrient flows in international trade: ecology and policy issues. Environ. Sci. Policy 8, 439-451.

29. Galloway, J.N., Dentener, F.J., Capone, D.G., Boyer, E.W., Howarth, R.W., Seitzinger, S.P., Asner, G.P., Cleveland, C., et al. 2004. Nitrogen cycles: past, present and future. Biogeochem. 70, 153-226.

30. Gleick, P.H. 2003. Water use. Ann. Rev. Env. Res. 28, 275-314.

31. Johnson, N., Revenga, C. and Echeverria, J. 2001. Managing water for people and nature. Science 292, 1071-1072.

32. Horrigan, L., Lawrence, R.S. and Walker, P. 2002. How sustainable agriculture can address the environmental and human health harms of industrial agriculture. Environ. Health Persp. 110, 445-456.

33. OECD, 2000. Impacts of Environmental Regulations in Intensive Livestock Production in the Netherlands. Organisation for Economic Co-operation and Development, Paris, France, $97 \mathrm{pp}$.

34. Cornish, G., Bosworth, B., Perry, C. and Burke, J. 2004. Water Charging in Irrigated Agriculture-An Analysis of International Experience. FAO Water Reports, FAO, Rome, Italy, $97 \mathrm{pp}$.

35. Turner, C.R., Kleih, U., Grashaw, R. and Phillips, M. 2004. Economic Valuation of Water Resources in Agriculture - From the Sectoral to a Functional Perspective of Natural Resource Management. FAO, Rome. (http://www.fao.org/docrep/007/y5582e/ y5582e00.HTM)

36. United States Department of Agriculture. 2002. National Agriculture Statistics Survey. (http://www.nass.usda.gov/index.asp)

37. McGuire, V.L. 2004. Water-Level Changes in the High Plains Aquifer, Predevelopment to 2002, 1980 to 2002, and 2001 to 2002. U.S. Geological Survey Fact Sheet FS-2004 3026,6 p.

38. Fleischner, T.L. 1994. Ecological costs of livestock grazing in western North America. Conserv. Biol. 8, 629-644.

39. Pretty, J., Brett, C. Gee, D., Hine, R., Mason, C., Morrison, J., Rayment, M., van der Bijl, G., et al. 2001. Policy challenges and priorities for internalizing the externalities of modern agriculture J. Environ. Plan Ma.44,263-283.

40. Fearnside, P.M. 2001. Soybean cultivation as a threat to the environment in Brazil. Environ. Conserv. 28, 23-38.

41. Kaimowitz, D. and Smith, J. 1999. Soybean technology and the loss of natural vegetation in Brazil and Bolivia. In: Agricultural Technologies and Tropical Deforestaion. Angelsen, A. and Kaimowitz, D. (eds). CABI Publishing, New York, pp. 195-212.

42. Kaimowitz, D., Mertens, B., Wunder, S. and Pacheco, P. 2004. Hamburger Connection Fuels Amazon Destruction. Center for International Forestry Research, Jakarta, Indonesia, $10 \mathrm{pp}$

43. Oenema, O. and Berentsen, P. 2005. Manure Policy and MINAS: Regulating Nitrogen and Phosphorus Surpluses in Agriculture of the Netherlands. OECD, Paris. (www.oecd. org/topicdocumentlist $/ 0,3024$,en $3387310833873626 \quad 1 \quad 1 \quad 1 \quad 1 \quad 37465,00 . h t m l)$

44. Lobell, D. B., Ivan Ortiz-Monasterio, J.I. and Asner, G.P. 2004 . Relative importance of soil and climate variability for nitrogen management in irrigated wheat. Field Crops Res. $87,155-165$.

45. Pimentel, D., Berger, B., Filiberto, D., Newton, M., Wolfe, B., Karabinakis, E., Clark, S., Poon, E., et al. 2004. Water Resources, Agriculture and the Environment. Report 04 1. College of Agriculture and Life Sciences, Cornell University, Ithaca, New York, 46 $\mathrm{pp}$. 
46. Rosegrant, M.W., Cai, X. and Cline, S.A. 2002. Global Water Outlook to 2025: Averting an Impending Crisis. A 2020 Vision for Food, Agriculture, and the Environment Initiative. International Food Policy Research Institute (IFPRI) and International Water Management Institute (IWMI), Washington, DC and Colombo, Sri Lanka, $26 \mathrm{pp.}$

47. Morton, D.C., DeFries, R.S., Shimabukuro, Y.E., Anderson, L.O., Arai, E., del Bon Espirito-Santo, F. Freitas, R and Morisette, J. 2006. Cropland expansion changes deforestation dynamics in the southern Brazilian Amazon. $P$. Natl Acad Sci. 103 , 14637-14641.

Gerber, P. Verburg, P. H Rosales, M., Ibrahim, M and Steinfeld, $\mathrm{H}$. 2007. Projecting land use changes in the Neotropics: the geography of pasture expansion into forest. Global Environ. Chang. 17, 86-104.

49. Margulis, S. 2003. Causes of Deforestation of the Brazilian Amazon. World Bank Publications, Washington, DC, $77 \mathrm{pp}$

50. Anderson, K. and Martin, W. 2005. Agricultural trade reform and the Doha development agenda. The World Econ. 28, 1301-1327.

1. We are grateful to the Woods Institute for the Environment, Environmental Ventures Program, Stanford University, SCOPE-CIAP, FAO-LEAD, the International Nitrogen Initiative, and The Ecosystem Center at the Marine Biological Laboratory for providing support, funding, and/or facilities for the project. We appreciate the help of, and interactions with, Anne Priest, Jackie Alder, Arjen Hoekstra, Taikan Oki, and Halton Peters during several workshops where this paper was one of the topics of discussion.

52. Dedication: G Eric Bradford (1929-2007). We dedicate this paper to our friend, colleague and c0-author, Eric Bradford, who died on July 29, 2007. We will miss his Be 50 years at the University of California (Davis) he served in many academic and administrative positions and was an innovator in animal science from the local to the international level. He had a deep passion for the creation of sustainable agricultural programs and towards that end he chaired an international task force that prepared a report on "Animal Agriculture and Global Food Supply," published by the Council for Agricultural Science and Technology in 1999. He had many honors, including election as a Fellow of the American Association for the Advancement of Science and of the American Society of collaborative research. As a measure of his devotion to science, Eric provided material for this paper up to the day he died. We owe him enormous thanks for not only his contributions to this paper, but also to science in general

53. First submitted 15 December 2006. Accepted for publication 26 April 2007.
James N. Galloway is Professor of Environmental Science at the University of Virginia. His research on biogeochemistry includes natural and anthropogenic controls on chemical cycles at the watershed, regional and global scales. His address: Department of Environmental Sciences, University of Virginia, 291 McCormick Rd., Charlottesville, VA 22904, USA.

E-mail: jng@ virginia.edu

Marshall Burke is Program Manager at the Program on Food Security and the Environment at Stanford University. He studies the effects of agricultural development on poverty alleviation and the environment in developing countries. His address: Program on Food Security and the Environment, Stanford University, Encina Hall 417E, Stanford, CA 94305-6055, USA.

E-mail: mburke@stanford.edu

G. Eric Bradford, Professor Emeritus in the Department of Animal Science came to UC Davis as a faculty member in 1957. $\mathrm{He}$ has devoted his career to the genetics of reproduction and growth in livestock and laboratory animals and has worked extensively in international animal agriculture. His address: Animal Science Department, University of California, Davis, 1 Shields Ave., Davis, CA 95616, USA.

E-mail: gebradford@ucdavis.edu

Rosamond Naylor is the Wrigley Senior Fellow at the Woods Institute for the Environment and the Freeman Spogli Institute for International Studies, and Associate Professor (by courtesy) in Economics at Stanford University. She is the Director of Stanford's new program in Food Security and the Environment. Her research focuses on the environmental and equity dimensions of intensive food production regionally and globally. Her address: Program on Food Security and the Environment, Encina Hall 418E, Stanford University, Stanford, CA 94305-6055, USA. E-mail: roz@stanford.edu

Walter Falcon is Farnsworth Professor of International Agricultural Policy (Emeritus) at Stanford University. His research focuses on poverty alleviation, climate change, and agricultural development, particularly with respect to Indonesia and Mexico. His address: Program on Food Security and the Environment, Stanford University, Encina Hall 402E, Stanford, CA 94305-6055, USA.

E-mail: wpfalcon@stanford.edu

Ashok K. Chapagain is a civil engineer working in the Department of Irrigation in Nepal. He also works as a full time consultant to WWF-UK advising on issues related to sustainable consumption and global fresh water resources. His $\mathrm{PhD}$ explores the hidden dimensions of the international trade and its impact on global water resources. His address: University of Twente, Faculty of Engineering Technology, CTW BuildingW105, PO Box 217, 7500 AE Enschede, The Netherlands.

E-mail: a.chapagain@gmail.com
Joanne C. Gaskell is working on her dissertation regarding food security and the environment with Stanford University's Interdisciplinary Program in Environment and Resources. Her address: Interdisciplinary Graduate Program in Environment and Resources, Stanford University, 397 Panama Mall, Mitchell Building, Room 132, Stanford, CA 94305-2210, USA.

E-mail: jgaskell@stanford.edu

Ellen McCullough is an economist in the Agricultural Development Economics division of the FAO. Her work focuses on organizational changes in food systems in developing countries and their impacts on smallholder agriculture. Her address: Agricultural and Development Economics Division, Food and Agriculture Organization, Rome 00153, Italy.

E-mail: ellen.mccullough @ fao.org

Harold A. Mooney is a Professor of Environmental Biology at Stanford University. He works on global ecological issues including impacts of global changes on biological diversity and ecosystem processes. His address: Department of Biological Sciences, Stanford University, Stanford, CA 94305, USA.

E-mail: hmooney@stanford.edu

Kirsten L. L. Oleson is completing her dissertation on ethics and sustainability of natural resource wealth in the Interdisciplinary Program in Environment and Resources at Stanford University. Her address: Interdisciplinary Graduate Program in Environment and Resources, Stanford University, Encina Hall 501E, Stanford, CA 94305, USA.

E-mail: koleson@stanford.edu

Henning Steinfeld is Chief of the Livestock Policy Branch at FAO in Rome, Italy. He works on livestock sector analysis and advice to member countries. His address: Animal Production and Health Division, Food and Agriculture Organization, Rome 00153, Italy.

E-mail: henning.steinfeld@fao.org

Tom Wassenaar is a researcher with the Institute for the Protection and Security of the Citizen, at the Joint Research Centre of the European Commission. His research covers environmental and geographical issues related to the Common Agricultural Policy of the EU. His address: Joint Research Centre of the European Commission, IPSC, AgriFish unit, TP 266, Via E. Fermi 1, 21020 Ispra (VA), Italy.

E-mail: tom.wassenaar@jrc.it

Vaclav Smil is Professor in the Faculty of Environment at the University of Manitoba; his research deals with interactions of energy, population, economy, food and environment. His address: Faculty of Environment, University of Manitoba, Winnipeg, MB R3T 2N2, Canada.

E-mail:vsmil@cc.umanitoba.ca 